\title{
Trivalent Chromium Promotes Healing of Experimental Colitis in Mice by Suppression of Inflammation and Oxidative Stress
}

\author{
Olugbenga Adeola Odukanmi ${ }^{1,2 *}$, Adeola Temitope Salami ${ }^{1}$, Koyo Koda ${ }^{2}$, \\ Oyenike Lola Morakinyo', Samuel Babafemi Olaleye ${ }^{1}$
}

\author{
${ }^{1}$ Laboratory for Gastrointestinal Secretion and Inflammation, Department of Physiology, College of Medicine, University of Iba- \\ dan, Ibadan, Nigeria \\ ${ }^{2}$ Department of Biotechnology, Maebashi Institute of Technology, Maebashi, Japan \\ Email: ^odukanmi@yahoo.com, adeolathabitha@yahoo.com, koyo190920@gmail.com, nikkymorax@gmail.com, \\ sbolaleye@yahoo.com
}

\begin{abstract}
How to cite this paper: Odukanmi, O.A., Salami, A.T., Koda, K., Morakinyo, O.L. and Olaleye, S.B. (2017) Trivalent Chromium Promotes Healing of Experimental Colitis in Mice by Suppression of Inflammation and Oxidative Stress. Journal of Biosciences and Medicines, 5, 108-126.

https://doi.org/10.4236/jbm.2017.58009
\end{abstract}

Received: July 18, 2017

Accepted: August 18, 2017

Published: August 21, 2017

Copyright $\odot 2017$ by authors and Scientific Research Publishing Inc. This work is licensed under the Creative Commons Attribution International License (CC BY 4.0).

http://creativecommons.org/licenses/by/4.0/

\begin{abstract}
Ulcerative colitis (UC) has reactive oxygen species (ROS) and immunologic pathways implicated in its pathogenesis. The search for new therapeutic protocols in managing UC is tailored in suppressing or preventing these pathways. The influence of trivalent chromium $\left(\mathrm{Cr}^{3+}\right)$, an essential mineral on experimental colitis was investigated. Mice were grouped into 3; group 1 (control) received clean drinking water while groups 2 and 3 received 10 and 100 ppm $\mathrm{Cr}^{3+}$ respectively for 12 weeks through drinking water. After $\mathrm{Cr}^{3+}$ administration, 5 animals per group were sacrificed on day 0 . Thereafter, experimental colitis was induced intra-rectally using acetic acid $(4 \%, 0.3 \mathrm{~mL})$ and 5 mice per group were subsequently sacrificed on days 3,7 and 14 . Blood and colonic tissues were obtained and processed appropriately. Blood $\mathrm{Cr}^{3+}$ level, haematological variables, gross and microscopic colitis scores, colonic myeloperoxidase (MPO), Superoxide Dismutase (SOD) and malondialdehyde (MDA) levels were determined using standard methods. Colon cytokine mRNA genes were quantified using real-time PCR. There was a significant decrease in colon gross and histology scores on days 3 and 7 in chromium treated compared with control. The MPO and MDA in chromium groups reduced significantly compared with control while SOD activities increased significantly in $\mathrm{Cr}^{3+}$ groups compared with control. Total RNA increased in chromium groups compared with control on day 3 post-colitis. There was up-regulation of IL-10, down-regulation of TNF- $\alpha$ and IFN- $\lambda$ in chromium administered groups compared with control. Chromium enhanced healing of colitis by suppression of ROS, inflammation and promotion of antioxidant activities.
\end{abstract}




\section{Keywords}

Colitis, Oxidative Stress, Trivalent Chromium, Inflammation, Mice

\section{Introduction}

Inflammatory bowel disease (IBD) comprises of both ulcerative colitis (UC) and Crohn's disease (CD) which is often characterized by extensive and severe intestinal inflammation resulting from deranged immune system in response to increasing loads of commensal micro-biota [1]. Although, the pathophysiology is still vague, reactive oxygen species (ROS) and immunologic processes are key theories that have been proposed as the possible mechanism of its pathologic nature [2] [3] [4] [5]. This has driven the search for therapeutic strategies that can be focused or targeted to the needs of individual patients. Conditions such as the patient's genetic components, disease states, and environmental influences have all played vital roles in the treatment and prognosis of the disease [5] [6]. Nevertheless, increase in antioxidant activities are also known to provide relieve for these conditions [7] [8].

Chromium, specifically trivalent $\left(\mathrm{Cr}^{3+}\right)$ is an essential mineral that human requires in trace amounts, although its mechanism of actions and the quantity that is beneficial to health have no clear-cut definitions [9]. It exists mainly in two forms, trivalent which are the more stable bio-available forms and present in food substances; hexavalent, the toxic form available from industrial pollutions. Chromium in this study is limited to trivalent form and has been reported to promote actions of insulin [10] [11], aid metabolism of fats, carbohydrates and protein [12] [13], among other beneficial effects.

The non-specificity of available treatment in the clinical management of ulcerative colitis and the increasing use of trivalent chromium as dietary supplement have increased our curiosity towards evaluating the probable activities of oral chromium on normal colon and experimental colitis. This study aim was to investigate the effect of chromium exposure basically on the reactive oxygen species and inflammatory pathways in both normal and experimental colitis in mice.

\section{Materials and Methods}

\subsection{Ethical Considerations}

This study was carried out in strict adherence to the recommendations in the Guide for the Care and Use of Laboratory Animals released by US National Institute of Health [14]. The protocol was approved by the Committee of Animal Care and Use of Maebashi Institute of Technology, Japan (No. 15-009).

\subsection{Animals and Treatment Protocols}

Sixty male, slc:ddY mice ( $25.3 \pm 2.1 \mathrm{~g}, 5$ weeks old) were purchased from SLC 
Incorporation, Japan, kept in the animal room at the Department of Biotechnology, Maebashi Institute of Technology and were used for the experiments. The animals were acclimatized for 2 weeks with access to standard feeds and water ad libitum. They were grouped into 3: Control $(n=20)$ were allowed free access to clean drinking water and groups 2 and 3, were administered oral 10 ppm, $(\mathrm{n}=20)$ and $100 \mathrm{ppm}(\mathrm{n}=20)$ trivalent chromium respectively through their drinking water for 12 weeks.

\subsection{Chemicals and Drugs}

Chromium was obtained from Koshin Chemicals, Japan. Hexadecyltrimethylammonium Bromide, o-Dianisidine Dihydrochloride, and Sodium nitrite were procured from Tokyo Chemical Industry, Co., Limited, Japan. All Other chemicals were of highest purity and analytical grade. RNA retraction and reverse transcription kits were obtained from Qiagen, Japan. Real-time PCR kits were obtained from Brilliant Agilent ${ }^{\circledR}$, UK; Primers for standards and RT-PCR assays all from qStandard ${ }^{\circledR}$, London.

\subsection{Acute Colitis Induction, Stool Consistency and Gross Assessment of Colonic Damage}

After $\mathrm{Cr}^{3+}$ exposure, mice ( $\mathrm{n}=5$ per group) were sacrificed (day 0 ) for gross, histology, haematological variables, biochemical parameters and gene expression studies. Thereafter, experimental colitis was induced using the modified method by Choudhary et al. (2001) [15]. Briefly, $0.1 \mathrm{~mL}$ of $4 \%$ acetic acid was introduced using a $3 \mathrm{~mm}$ soft paediatric catheter which was advanced $3 \mathrm{~cm}$ from anal opening under light ketamine anaesthesia $(0.01 \mathrm{~mL} / \mathrm{g})$ for 60 seconds in $24 \mathrm{~h}$ fasted mice. Mice were maintained in a head-down position for 30 seconds following introduction of acetic acid to prevent immediate extrusion of the solution (Control had normal saline of the same proportion instilled). Stool consistency was scored starting from $24 \mathrm{~h}$ post induction and daily for 7 days after colitis induction using the method described by Fukuda et al. [16] where $0=$ normal stool, 1 = loose stool without visible blood, 2 = loose stool with visible blood, $3=$ bloody diarrhea. The mice were anaesthetized with xylaxine $(0.0005 \mathrm{~mL} / \mathrm{g})$ and ketamine $(0.015 \mathrm{~mL} / \mathrm{g})$ cocktails. Thereafter, laparotomy was conducted and the distal $8 \mathrm{~cm}$ of the colon was resected for gross colitis scores, histology, biochemical assessment and cytokine mRNA gene expression on day 0 (before colitis induction) and days 3, 7 and 14 after induction of colitis in the mice. The gross scoring method described by Morris et al. [17] where, no damage $=0$, localized hyperemia with no ulcers $=1$, linear ulcers with no significant inflammation $=2$, linear ulcer with inflammation at one site $=3$, more site of ulcers and inflammation, the size of ulcer $<1 \mathrm{~cm}=4$ and multiple inflammations and ulcers, the size of ulcer $>1 \mathrm{~cm}=5$ was adopted.

\subsection{Histology and Histomorphometry Assessment of Colon Tissues}

All sections for light microscopy were fixed in 10\% buffered formalin, embedded 
in paraffin wax, sectioned, and stained with haematoxylin and eosin (H\&E). Accuscope TS view, China was used to capture images and to evaluate morphological changes and measurement of histomorphometry variables.

\subsection{Determination of Blood Parameters}

Blood samples $(1 \mathrm{~mL})$ were analyzed using an automated machine following blood sample collection from cardiac puncture into a $5 \mathrm{~mL}$ heparinized bottle. Each of the samples collected were ran sequentially using KX-21 haematological analyzer by Symex Kobe ${ }^{\circledR}$ Japan.

\subsection{Lipid Peroxidation Determination}

This was assessed by measuring the formation of thiobarbituric acid reactive substances (TBARS) according to the method described by Varshney and Kale [18]. The method described the value of malondialdehyde (MDA) in the tissue homogenates during lipid peroxidation with thiobarbituric acid (TBA) forming a pinkish MDA-TBA complex that was read spectrophotometrically at $532 \mathrm{~nm}$.

\subsection{Determination of Antioxidant Status in Colonic Tissues}

Catalase activity was determined according to the method described by Sinha [19]. The procedure described the reduction of dichromate in the presence of acetic acid to chromic acetate when heated in the presence of $\mathrm{H}_{2} \mathrm{O}_{2}$, with the formation of perchromic acid as an unstable intermediate. The resultant chromic acetate was determined spectrophotometrically at $530 \mathrm{~nm}$. Superoxide Dismutase (SOD) method described by Misra and Fridovich [20] was adopted using $0.5 \mathrm{~mL}$ of tissue homogenates which was added to $2.5 \mathrm{ml}$ of $0.05 \mathrm{M}$ carbonate buffer at $\mathrm{pH} 10.2$ to equilibrate in glass cuvette. The reaction commenced with the addition of $0.3 \mathrm{~mL}$ freshly prepared $0.3 \mathrm{mM}$ epinephrine. Increase in absorbance at $480 \mathrm{~nm}$ was observed every $30 \mathrm{~s}$ for $1 \mathrm{~min}$ and 1 unit of SOD activity was given as amount of SOD expected to cause $50 \%$ inhibition of the oxidation of adrenaline.

\subsection{Determination of Total Nitrite}

Total tissue nitrite determination was done using the method described by Ignarro et al. [21]. The assay relies on a diazotization reaction that was originally described by Griess [22], which uses sulfanilamide and $N$-1-napthylethylenediamine dihydrochloride (NED) under acidic (phosphoric acid) conditions.

\subsection{Determination of Myeloperoxidase Activity}

The method described by Kim et al. [23] was adopted using tissue homogenates.

\subsection{RNA Extraction and Quantification of Absolute Real-Time PCR}

Total RNA was obtained with RNeasy Mini Kit from Qiagen, Japan and the 
protocol was followed strictly. Briefly, $30 \mathrm{mg}$ of sample were stored in RNAlater RNA stabilization reagent, $\left(\right.$ Qiagen $\left.^{\circledR}\right)$ pending homogenization. Tissue was thawed on ice and subsequently homogenized after lysing with appropriate lysing buffer at $4^{\circ} \mathrm{C}$. The lysate was centrifuged for 3 minutes at maximum speed and supernatant was carefully pipetted. Ethanol (70\%) was added to the pipetted supernatant, volume for volume and mixed well. The mixture $(700 \mu \mathrm{L})$ was added to $2 \mathrm{~mL}$ RNeasy spin column and centrifuged for 15 seconds at $>8000 \mathrm{x} \mathrm{g}$. The flow-through was discarded and another $700 \mu \mathrm{L}$ wipeout buffer (RW1) added to the spin column, this was centrifuged at $>8000 \mathrm{x}$ g for $15 \mathrm{sec}$.

The flow-through was also discarded and $500 \mu \mathrm{L}$ RPE buffer added to wash out membrane-bound RNA and also centrifuged for 15 seconds at $>8000 \mathrm{x} \mathrm{g}$. This was repeated for 2 minutes. The spin-column is now placed in a new collection tube and spin for 1 minute to dry the membrane. Then $50 \mu \mathrm{L}$ of RNase-free water was added to the column directly and centrifuged for 1 minute at $>8000 \mathrm{x}$ $\mathrm{g}$ to elute the RNA. The eluted fraction was quantified using $1 \mu \mathrm{L}$ of total RNA sample on Nanodrop ${ }^{\circledR} 2000$ spectrophotometer at $260 / 280 \mathrm{~nm}$. Total RNA was further expressed on 2\% Agarose gel electrophoresis. The eluted RNA was then stored at $-80^{\circ} \mathrm{C}$ pending reverse transcription, thereafter $150 \mathrm{ng} / \mu \mathrm{L}$ RNA was reverse transcribed into complementary DNA.

QuantiTect Reverse Transcription Kit from Qiagen ${ }^{\circledR}$ was used and all reactions set-up was on ice. Briefly, genomic DNA elimination reaction was done using gDNA wipeout buffer, template RNA and RNase-free water mixture incubated for 2 minutes at $42^{\circ} \mathrm{C}$, then returned immediately on ice. The reversetranscriptase master mix was constituted with $1 \mu \mathrm{L}$ Quantiscript reverse transcriptase, $4 \mu \mathrm{L}$ Quantiscript RT Buffer and $1 \mu \mathrm{L}$ RT Primer mix all added to the entire purified genomic DNA reaction described above and quickly returns on ice. This was incubated for 15 minutes at $42^{\circ} \mathrm{C}$. Incubation was repeated for 3 minutes at $95^{\circ} \mathrm{C}$ to inactivate Quantiscript Reverse Transcriptase. The reverse-transcription reaction was then placed on ice and immediately proceeds for real time PCR. Prior to use in PCR, the cDNA was diluted 10-folds (1:10) by tRNA $(10 \mu \mathrm{g} / \mathrm{mL})$, to reduce contamination if any.

Thereafter, Brilliant III Ultra-Fast SYBR ${ }^{\circledR}$ Green QPCR Master Mix obtained from Agilent Technologies, UK. Standard assays, primers and cytokine assays were all gotten from qStandards ${ }^{\circledR}$, UK with the following document number for standards, mmu_Actb_001; mmu_Gapdh_001; mmu_Rpl13_002; mmu_Ifng_001, mmu_Il1a_001; mmu_Il6_001; mmu_Il10-001 and mmu_Tnf_001 were used. Applied Biosystems ${ }^{\circledR} 7500$ Fast Real-Time PCR System was used to amplify the eight mRNA genes, three were reference genes (B-Actin, Gapdh and Rpl13) and five cytokines of interest (IL- $1 \alpha$, IL-6, IL-10, TNF- $\alpha$ and IFN- $\lambda$ ) (Table 1).

The protocols were strictly followed. Briefly, a total volume of $20 \mu \mathrm{L}$ was used for the PCRs. $4 \mu \mathrm{L}$ diluted cDNA, $10 \mu \mathrm{L}$ Brilliant III SYBR green mix, $1 \mu \mathrm{L}$ forward primer, $1 \mu \mathrm{L}$ reverse primer and $4 \mu \mathrm{L}$ Samples were first denatured at $95^{\circ} \mathrm{C}$ for $3 \mathrm{~min}$, this was followed by amplification for 40 cycles; denaturation, $95^{\circ} \mathrm{C}$ 
Table 1. Oligonucleotide primers used for real time quantitative PCR.

\begin{tabular}{|c|c|c|}
\hline \multicolumn{3}{|c|}{ Primer Sequence } \\
\hline Genes & Forward & Reverse \\
\hline$\beta$-actin & $5^{\prime}$-caccatgaagatcaagatcattgct-3' & 5'-taaaacgcagctcagtaacagt-3' \\
\hline GAPDH & 5'-catttcctggtatgacaatgaatacg-3' & 5'-ggatagggcctctcttgctc-3' \\
\hline RPL13 & 5'-tgattggcgtttgagattggc-3' & $5^{\prime}$-gcttcagtatcatgccattccg-3' \\
\hline IFN- $\lambda$ & 5'-cggcacagtcattgaaagcc-3' & 5'-tgtcaccatccttttgccagt-3' \\
\hline IL- $1 \alpha$ & 5'-cgcttgagtcggcaaagaaat-3' & 5'-tggcagaactgtagtcttcgt-3' \\
\hline IL-6 & 5'-gccttcttgggactgatgct-3' & 5'-gccattgcacaactcttttctca-3' \\
\hline IL-10 & 5'-gccgggaagacaataactgc-3' & 5'-ttggcaacccaagtaaccct-3' \\
\hline TNF- $\alpha$ & 5'-gtctactgaacttcggggtgat-3' & 5 -tgagaagatgatctgagtgtgagg- 3 \\
\hline
\end{tabular}

for $5 \mathrm{sec}$, annealing and extension was at $60^{\circ} \mathrm{C}$ for 27 seconds and ramping was done between $65^{\circ} \mathrm{C}$ and $95^{\circ} \mathrm{C}$ rising by $1^{\circ} \mathrm{C}$ per step. Polymerase chain reaction amplification was performed in triplicate. The standard curves for each gene were generated using the specific standard fragments from qStandards ${ }^{\circledR}$. The absolute copy numbers were generated by the PCR machine and the amounts determined by normalization against the three reference genes were subsequently analyzed.

The RNA and PCR products were subjected to electrophoresis on $1.5 \%$ Agarose gels with $1 \times$ running buffer Tris-Acetic acid-EDTA (TAE $\times 1$ ), at $50 \mathrm{~V}$ for $90 \mathrm{~min}$ and visualized by means of ethidium bromide stain under ultra violet light before they were transferred for digital gel photographs with Quantum LAS 4000 .

\subsection{Statistical Analysis}

Data were recorded as mean \pm S.E.M and analyzed using descriptive statistics one way ANOVA followed by a post-hoc test (Newman-Keul's comparison test) with GraphPad Prism version 5 (GraphPad software, San Diego, CA). Differences were considered significant at $\mathrm{P}<0.05$.

\section{Results}

\subsection{Effect of Oral Chromium on Stool Consistency in Acetic Acid-Induced Colitis}

The stool consistency scores were significantly low in the chromium groups by days 3, 4 and 5 following colitis induction compared with control group (Figure $1)$.

\subsection{Effects of Oral Chromium on Colon Macro and Micro Architecture (MAG X100), Pre- and Post-Induction of Colitis}

The colon histoarchitecture varied with significant increase in crypt heights in the chromium groups, $10 \mathrm{ppm}(163.1 \pm 10.59 \mu \mathrm{m})$ and $100 \mathrm{ppm}(165.71 \pm 12.26$ $\mu \mathrm{m})$ compared to control $(132.13 \pm 8.24 \mu \mathrm{m})$. Mucosa width increased signify- 


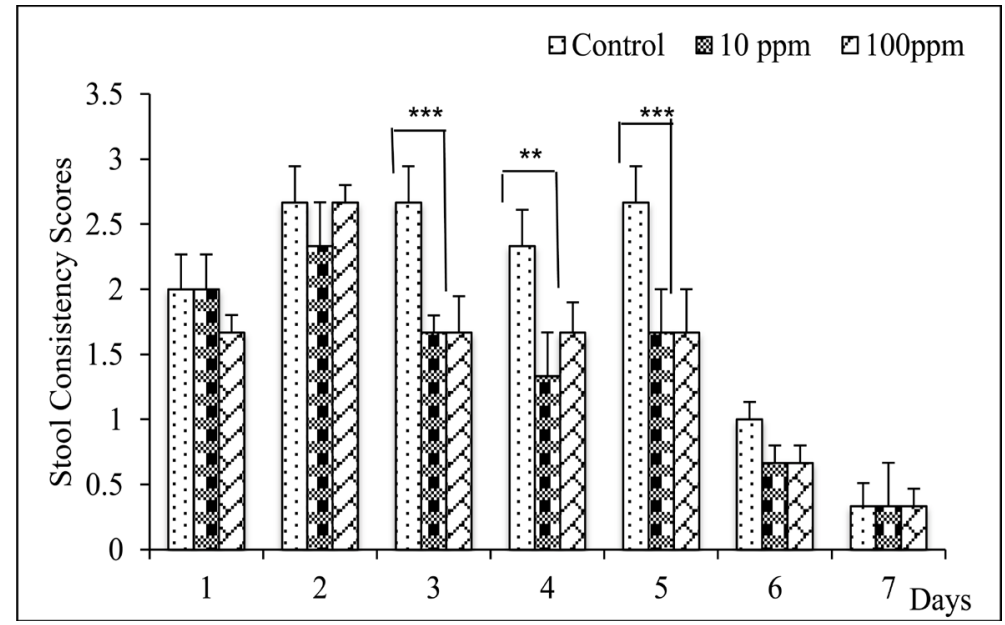

${ }^{\star *}$ Significant at $\mathrm{p}<0.01,{ }^{* *}$ significant at $\mathrm{p}<0.001$ compared with control.

Figure 1. Stool consistency post colitis induction in chromium administered groups and control.

Table 2. Effect of oral chromium exposure on colon architecture before colitis induction.

\begin{tabular}{|c|c|c|c|}
\hline Day 0 & Control & $10 \mathrm{ppm}$ & $100 \mathrm{ppm}$ \\
\hline \multicolumn{4}{|l|}{ Macroscopic } \\
\hline \multicolumn{4}{|l|}{ Microscopic } \\
\hline Gross Colitis Scores & $0.00 \pm 0.00$ & $0.00 \pm 0.00$ & $0.00 \pm 0.00$ \\
\hline Histology scores & $0.12 \pm 0.06$ & $0.08 \pm 0.06$ & $0.11 \pm 0.09$ \\
\hline Mucosa width $(\mu \mathrm{m})$ & $260.81 \pm 9.3$ & $273.01 \pm 6.44$ & $298.35 \pm 2.78^{+}$ \\
\hline Crypt height $(\mu \mathrm{m})$ & $132.13 \pm 8.24$ & $163.10 \pm 10.59^{*}$ & $165.71 \pm 12.26^{*}$ \\
\hline $\begin{array}{l}\text { Mucous Glandular } \\
\text { Unit/61,634.95 } \mu \mathrm{m}^{2}\end{array}$ & $48.25 \pm 3.57$ & $47.10 \pm 2.90$ & $50.25 \pm 4.56$ \\
\hline
\end{tabular}

The gross and histology of all tissues appears normal. ${ }^{*}$ significant difference at $\mathrm{p}<0.05$ compared with control (MAG. X100), H \& E stain.

cantly and not significantly only in the $100 \mathrm{ppm}(298.35 \pm 2.78 \mu \mathrm{m})$ compared with control $(260.81 \pm 9.3 \mu \mathrm{m})$ after exposure (Table 2). The control group on day 3 (Table 3 ) shows gangrenous and severe ulceration in both the gross and histology compared with the chromium treated groups with milder form of injuries. Day 7 (Table 4) shows an improved healing in all the groups studied.

\subsection{Effect of Oral Chromium Administration on Haematological Variables before and after Colitis Induction}

Table 5 shows significant increase in platelet counts on days 0 and 3 in $10 \mathrm{ppm}$ 
$(117.7 \pm 9.5 ; 187.7 \pm 30.3)$ and $100 \mathrm{ppm}(105.3 \pm 7.4 ; 181.0 \pm 28.8)$ chromium groups compared to the control $(78.9 \pm 4.1 ; 143.7 \pm 17.6)$, respectively. There

Table 3. Effect of oral chromium exposure on colon architecture 3 days after colitis induction.

\begin{tabular}{|c|c|c|c|}
\hline COLON DAY 3 & Control & $10 \mathrm{ppm}$ & $100 \mathrm{ppm}$ \\
\hline Macroscopic & $x-3 \quad 4 \quad 5,6$ & & $\begin{array}{llll}2 & 3 & 4 & 5\end{array}$ \\
\hline \multicolumn{4}{|l|}{ Microscopic } \\
\hline Gross Colitis scores & $4.52 \pm 0.88$ & $2.62 \pm 0.67^{+}$ & $2.38 \pm 0.60^{++}$ \\
\hline Histology scores & $4.32 \pm 0.81$ & $2.33 \pm 0.33^{+}$ & $2.07 \pm 0.33^{+}$ \\
\hline Mucosa width $(\mu \mathrm{m})$ & $217.12 \pm 9.3$ & $296.30 \pm 4.91^{++}$ & $339.70 \pm 7.26^{++}$ \\
\hline Crypt length $(\mu \mathrm{m})$ & $115.73 \pm 2.69$ & $119.60 \pm 5.08$ & $141.20 \pm 6.22^{+\#}$ \\
\hline $\begin{array}{l}\text { Mucous Glandular } \\
\text { Unit/61,634.95 } \mu^{2}{ }^{2}\end{array}$ & $38.33 \pm 1.46$ & $39.33 \pm 4.41$ & $40.67 \pm 1.77$ \\
\hline
\end{tabular}

The thick red arrow indicates dead area of the mucosa; thin red arrow shows points of inflammation on the colon tissues of 10 and $100 \mathrm{ppm}$. Blue arrows show degree of mucosa defects following colitis induction. ${ }^{+}$significant at $\mathrm{p}<0.05,{ }^{++}$significant at $\mathrm{p}<0.01$, compared with control, ${ }^{\#}$ significant at $\mathrm{p}<0.05$ compared with $10 \mathrm{ppm}$.

Table 4. Effect of oral chromium exposure on colon architecture after day 7 of colitis induction.

\begin{tabular}{|c|c|c|c|}
\hline COLON DAY 7 & Control & $10 \mathrm{ppm}$ & $100 \mathrm{ppm}$ \\
\hline \multicolumn{4}{|l|}{ Macroscopic } \\
\hline \multicolumn{4}{|l|}{ Microscopic } \\
\hline Gross Colitis scores & $1.63 \pm 0.33$ & $0.67 \pm 0.33^{+}$ & $0.00 \pm 0.00^{+}$ \\
\hline Histology scores & $3.45 \pm 0.51$ & $2.17 \pm 0.67^{+}$ & $1.40 \pm 0.37^{+}$ \\
\hline Mucosa width $(\mu \mathrm{m})$ & $282.90 \pm 10.34$ & $322.40 \pm 6.79$ & $318.2 \pm 14.71$ \\
\hline Crypt height $(\mu \mathrm{m})$ & $130.32 \pm 5.98$ & $155.41 \pm 8.97$ & $149.2 \pm 13.57$ \\
\hline $\begin{array}{l}\text { Mucous Glandular } \\
\text { Unit/61,634.95/ } \mathrm{mm}^{2}\end{array}$ & $40.67 \pm 1.2$ & $38.00 \pm 2.33$ & $40.67 \pm 2.08$ \\
\hline
\end{tabular}

Red arrow indicates ongoing inflammation in the gross colon tissue of control while the blue arrow shows persistent defects on the wall of the mucosa. ${ }^{+}$Significant at $\mathrm{p}<0.05$ compared with control. 
Table 5. Effect of oral chromium administration on haematological variables before and after colitis induction.

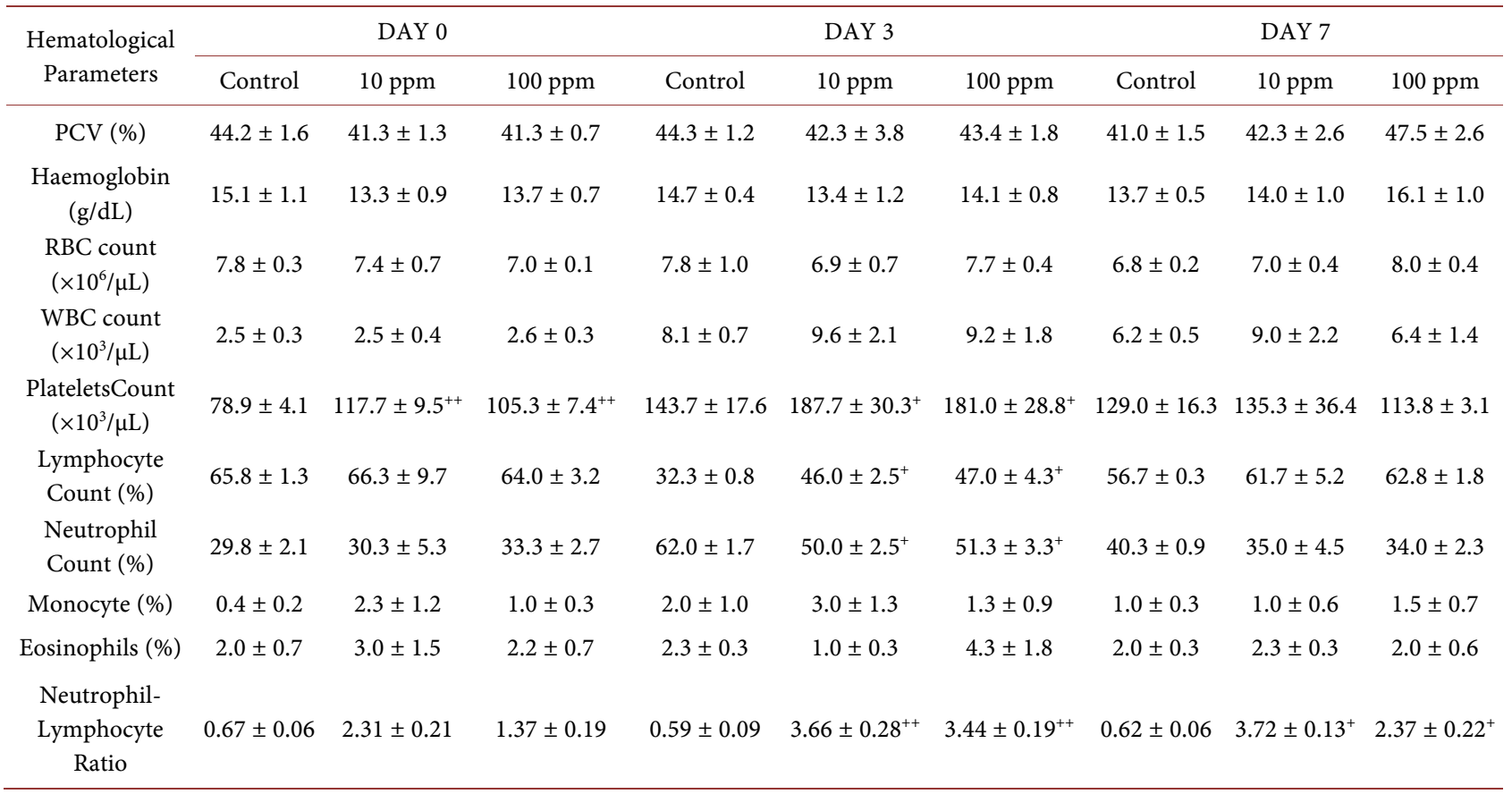

${ }^{+}$significant at $\mathrm{p}<0.05,{ }^{++}$significant at $\mathrm{p}<0.01$ compared with the control.

Table 6. Effect of oral chromium administration on biochemical parameters before and after colitis induction.

\begin{tabular}{|c|c|c|c|c|c|c|c|c|c|}
\hline \multirow{2}{*}{$\begin{array}{l}\text { Biochemical } \\
\text { Parameters }\end{array}$} & \multicolumn{3}{|c|}{ DAY 0} & \multicolumn{3}{|c|}{ DAY 3} & \multicolumn{3}{|c|}{ DAY 7} \\
\hline & Control & $10 \mathrm{ppm}$ & $100 \mathrm{ppm}$ & Control & $10 \mathrm{ppm}$ & $100 \mathrm{ppm}$ & Control & $10 \mathrm{ppm}$ & $100 \mathrm{ppm}$ \\
\hline \multicolumn{10}{|l|}{ Superoxide } \\
\hline $\begin{array}{c}\text { Dismutase }(\mu \mathrm{mol} / \mathrm{mg} \\
\text { protein })\end{array}$ & $6.93 \pm 0.67$ & $6.15 \pm 0.29$ & $6.11 \pm 0.50$ & $7.52 \pm 0.39$ & $9.39 \pm 0.22^{\star}$ & $9.42 \pm 0.16^{*}$ & $7.24 \pm 0.34$ & $8.78 \pm 0.38^{\star}$ & $8.70 \pm 0.29^{\star}$ \\
\hline $\begin{array}{c}\text { Catalase } \\
(\mu \mathrm{mol} / \mathrm{min} / \mathrm{mg} \\
\text { protein })\end{array}$ & $923.9 \pm 67.2$ & $1044.2 \pm 82.1$ & $1010.2 \pm 77.7$ & $1128.3 \pm 112.0$ & $1173.2 \pm 52.1$ & $1185.1 \pm 99.3$ & $993.0 \pm 88.4$ & $1160.1 \pm 73.3$ & $1140.0 \pm 97.3$ \\
\hline Tissue Total Nitrite & $0.11 \pm 0.01$ & $0.12 \pm 0.01$ & $0.13 \pm 0.01$ & $0.22 \pm 0.01$ & $0.19 \pm 0.01$ & $0.21 \pm 0.01$ & $0.19 \pm 0.01$ & $0.18 \pm 0.01$ & $0.18 \pm 0.01$ \\
\hline $\begin{array}{l}\text { Myeloperoxidase } \\
\text { (U/mg tissue) }\end{array}$ & $0.46 \pm 0.17$ & $0.34 \pm 0.17$ & $0.34 \pm 0.15$ & $3.08 \pm 0.24$ & $2.29 \pm 0.12^{*}$ & $1.82 \pm 0.26^{\star *}$ & $2.42 \pm 0.05$ & $1.77 \pm 0.19^{*}$ & $1.76 \pm 0.12^{*}$ \\
\hline
\end{tabular}

${ }^{*}$ significant at $\mathrm{p}<0.05,{ }^{* *}$ significant at $\mathrm{p}<0.01$ compared with control.

was also a significant increase in lymphocyte counts on day 3 in the $10 \mathrm{ppm}$ $(46.0 \pm 2.5)$ and $100 \mathrm{ppm}(47.0 \pm 4.3)$ compared with control $(32.3 \pm 0.8)$. Neutrophil reduced significantly in the chromium groups, $10 \mathrm{ppm}(50.0 \pm 2.5)$ and $100 \mathrm{ppm}(51.3 \pm 3.3)$ on day 3 compared with the control (62.0 \pm 1.7$)$ (Table 5).

\subsection{Effect of Oral Chromium Exposure on Biochemical Parameters Pre- and Post-Colitis Induction}

There was no significant change after period of exposure (on day 0 ) compared to days 3 and 7 after colitis induction (Table 6). The MDA values reduced signifi- 
cantly on days 3 and 7 in the chromium groups, $10 \mathrm{ppm}(4.18 \pm 0.17 ; 2.30 \pm$ $0.28)$ and $100 \mathrm{ppm}(4.17 \pm 0.22 ; 2.20 \pm 0.25)$ compared with control (5.36 \pm 0.30 ; $3.59 \pm 0.29)$ respectively, while SOD increased significantly on days 3 and 7 in the $10 \mathrm{ppm}(9.39 \pm 0.22 ; 8.78 \pm 0.38)$ and $100 \mathrm{ppm}(9.42 \pm 0.16 ; 8.70 \pm 0.29)$ compared with control (7.52 $\pm 0.39 ; 7.24 \pm 0.34)$ (Table 6), respectively. Table 6 further shows significantly reduced myeloperoxidase activities on days 3 and 7 in the $10 \mathrm{ppm}(2.29 \pm 0.12 ; 1.77 \pm 0.19)$ and $100 \mathrm{ppm}(1.82 \pm 0.26 ; 1.76 \pm 0.12)$ compared with control $(3.08 \pm 0.24 ; 2.42 \pm 0.05)$, respectively.

\subsection{Effect of Oral Chromium Exposure on Colon Cytokines mRNA and DNA Pre- and Post-Colitis Induction}

Plate 1 revealed depletion of 18 subunit of ribosomal RNA in all the groups on day 3 (after colitis induction) and a gradual return to normal days 7 and 14 . Figure 2 and Plate 2 shows a significant increase in the copy numbers of mRNA IL- $1 \alpha$ in the chromium groups compared with the control on day 3. Expression of IL-6 mRNA increased significantly in all the groups on day 3 compared to their counterparts on day 0 (Figure 3 and Plate 3). The expression of Interleukin-10 mRNA significantly increased in the chromium groups on days 3, 7 and 14 compared with control (Figure 4 and Plate 4). Figure 5, Plate 5 and Figure 6 , Plate 6 shows significant decrease in expressions of TNF- $\alpha$ and IFN- $\lambda$ mRNA in the chromium groups on days 7 and 14 compared with the control.

\section{Discussion}

This study emphasizes the effect of oral chromium administration on intact co-

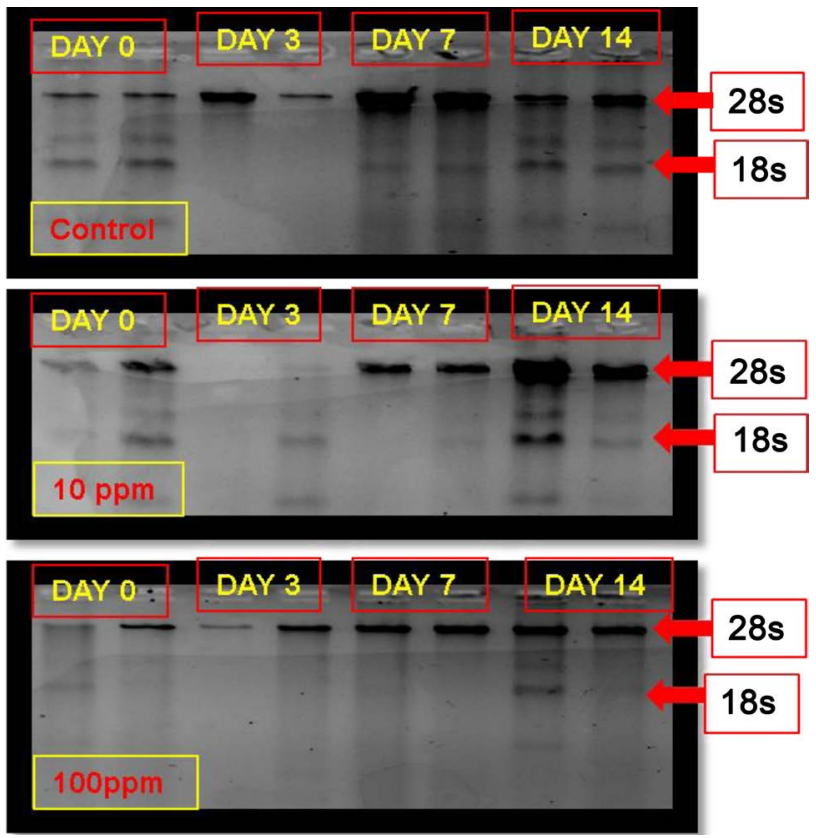

Plate 1. Colon total RNA on Agarose-Gel electrophoresis after oral chromium administration and colitis induction. It shows $28 \mathrm{~s}$ and $18 \mathrm{~s}$ ribosomal RNA bands, an important observation is the depletion of the $18 \mathrm{~s}$ bands especially on days 3 in almost all the groups. 


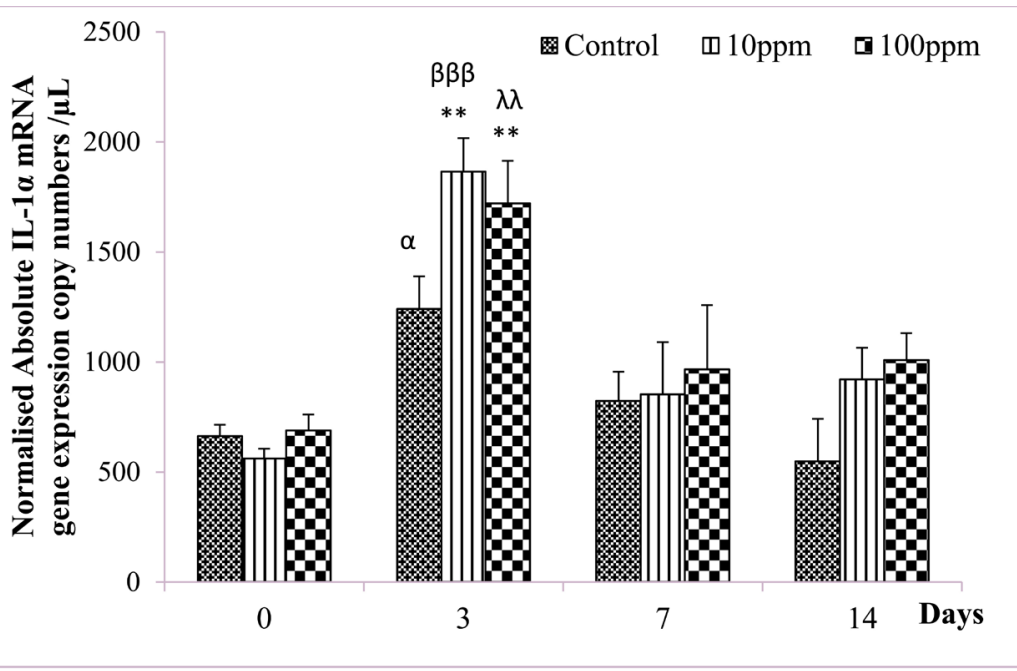

$\alpha$ - Significant at $\mathrm{p}<0.05$ compared with control on day 0 , ${ }^{*}$ significant at $\mathrm{p}<0.05$ compared with control, $\beta \beta \beta$ - significant at $\mathrm{p}<0.001$ compared with $10 \mathrm{ppm}$ on day $0 ; \beta \beta, \lambda \lambda$, -significant at $\mathrm{p}<0.01$ compared with $100 \mathrm{ppm}$ on day 0 .

Figure 2. Real-Time PCR Absolute copy numbers of colon IL- $1^{\alpha}$ mRNA gene expression following oral chromium administration before and after colitis induction. Values were normalised with the three reference genes, B-actin, GAPDH and RPL13.

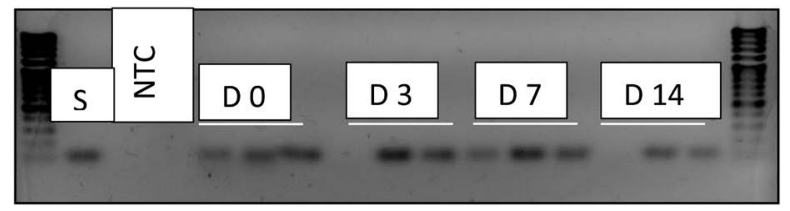

\section{IL-1 $\alpha$ mRNA}

D0 = Day 0, D3 = Day 3, D7 = Day 7 and D14 $=$ Day 14, S $=$ Standard, NTC $=$ No template control.

Plate 2. The plate represents the corresponding Agarose-Gel electrophoresis following real-time PCR amplification.

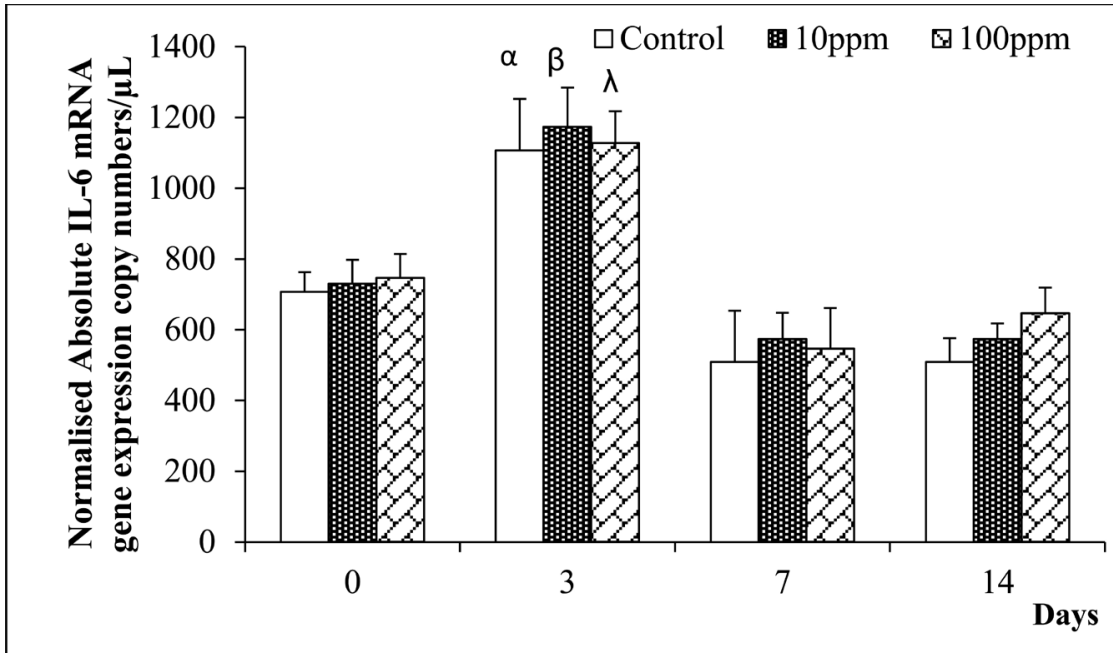

$\alpha$ - Significant at $\mathrm{p}<0.05$ compared with control on day $0, \beta$-significant at $\mathrm{p}<0.05$ compared with 10 ppm on day $0, \lambda$-significant at $\mathrm{p}<0.05$ compared with $100 \mathrm{ppm}$ on day 0 .

Figure 3. Real-Time PCR Absolute copy numbers of colon IL-6 mRNA gene expression following oral chromium administration before and after colitis induction. Values were normalised with the three reference genes, B-actin, GAPDH and RPL13. 


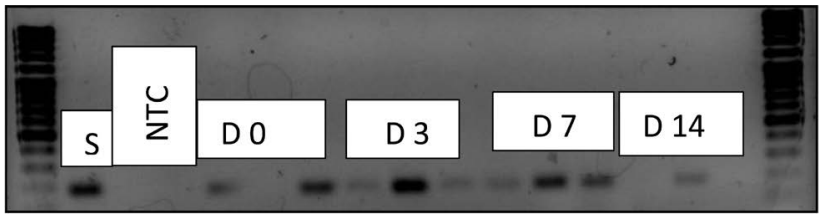

\section{IL-6 mRNA}

D0 = Day 0, D3 = Day 3, D7 = Day 7 and D14 = Day 14, S = Standard, NTC = No template control.

Plate 3. The plate represents the corresponding Agarose-Gel electrophoresis post realtime PCR amplification.

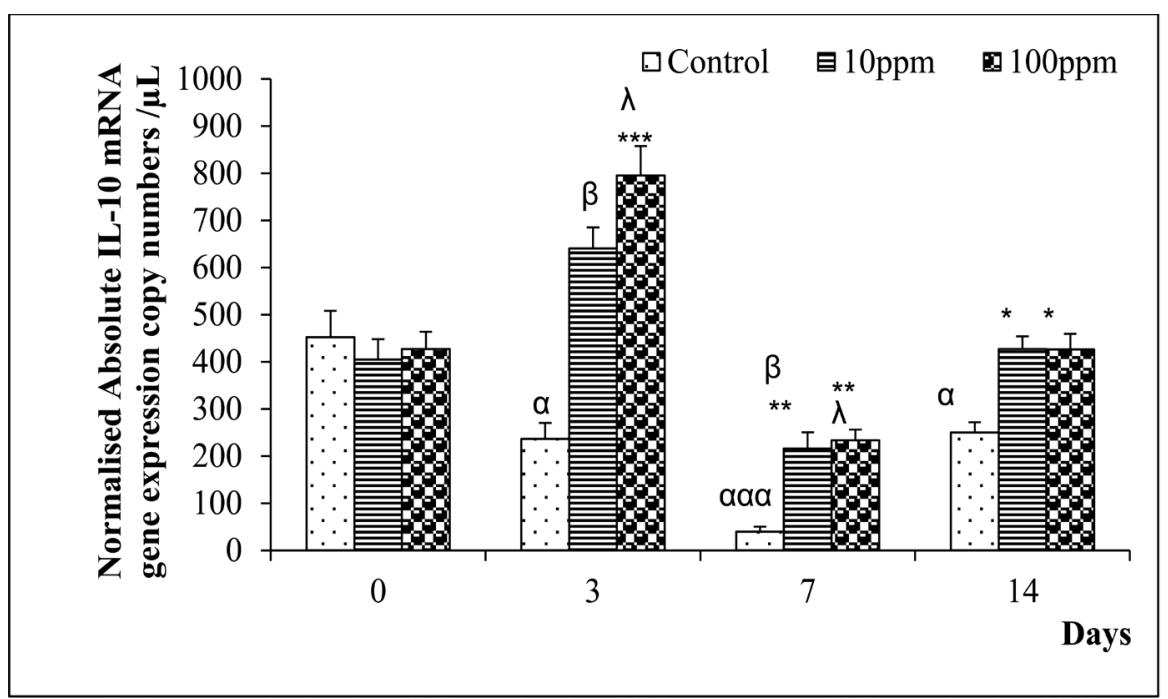

$\alpha$-significant at $\mathrm{p}<0.05$ compared with control on day $0, \alpha \alpha$-significant at $\mathrm{p}<0.05$ compared with control on day 0; $\alpha \alpha \alpha$-significant at $\mathrm{p}<0.001$ compared with control on day 0 ; ${ }^{*}$ significant at $\mathrm{p}<$ 0.05 compared with control on day $14,{ }^{* *}$-significant at $\mathrm{p}<0.01$ compared with control, ${ }^{* *}$-significant at $\mathrm{p}<0.001$ compared with control, $\beta$-significant at $\mathrm{p}<0.05$ compared with $10 \mathrm{ppm}$ on day 0 , $\lambda$-significant at $\mathrm{p}<0.05$ compared with $100 \mathrm{ppm}$ on day 0 .

Figure 4. Real-Time PCR Absolute copy numbers of colon IL-10 mRNA gene expression following oral chromium administration before and after colitis induction. Values were normalised with the three reference genes, B-actin, GAPDH and RPL13.

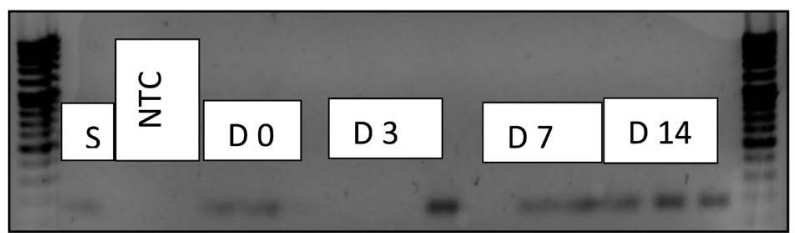

\section{IL-10 mRNA}

D0 $=$ Day 0, D3 $=$ Day 3, D7 $=$ Day 7 and D14 $=$ Day $14, S=$ Standard, NTC $=$ No template control

Plate 4. The plate represents the corresponding Agarose-Gel electrophoresis post realtime PCR amplification.

lon tissue and acetic acid-induced colitis in mice following the exposure period to chromium. The low scores for stool consistency reported in the test groups compared with control on days 3, 4 and 5 post inductions, is an indication of early recovery which was evident by gross and micro architecture rapid re-epithelization [24]. The increase in mucosa architecture is suggestive of colon mucosa growth enhancement. These findings underscore possible tissue toxicities from trivalent chromium administration. 


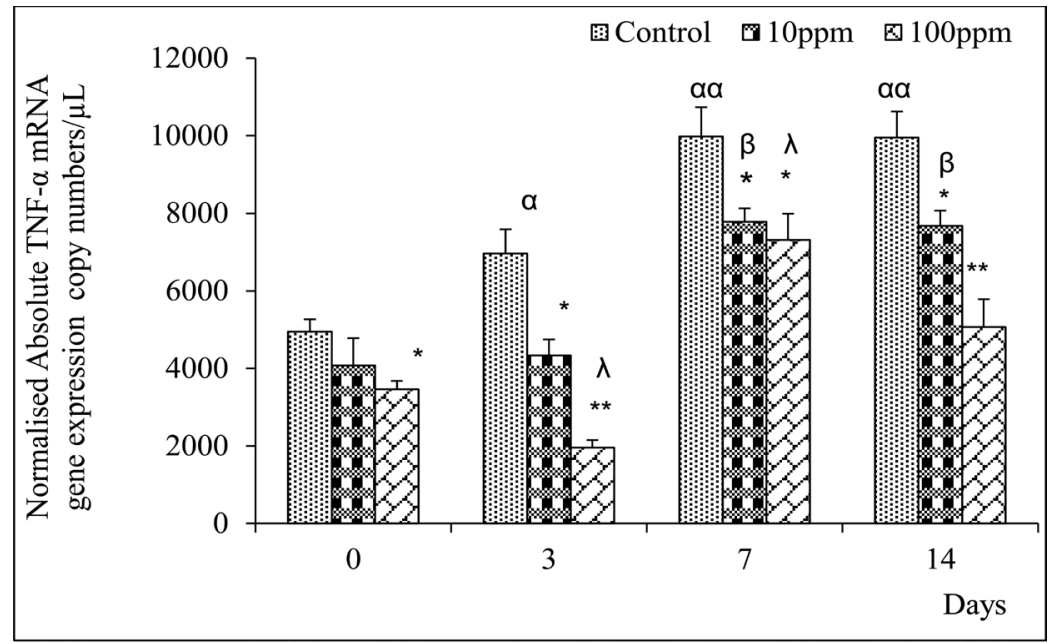

$\alpha$ - significant at $\mathrm{p}<0.05$ compared with control on day $0, \alpha \alpha$-significant at $\mathrm{p}<0.05$ compared with control on day 0 , ${ }^{*}$ significant at $\mathrm{p}<0.05$ compared with control on day $14,{ }^{* *}$-significant at $\mathrm{p}<0.01$ compared with control, $\beta$-significant at $\mathrm{p}<0.05$ compared with $10 \mathrm{ppm}$ on day $0, \lambda$-significant at $\mathrm{p}<$ 0.05 compared with $100 \mathrm{ppm}$ on day 0 .

Figure 5. Real-Time PCR Absolute copy numbers of colon TNF- $\alpha$ mRNA gene expression following oral chromium administration before and after colitis induction. Values were normalised with the three reference genes, B-actin, GAPDH and RPL13.

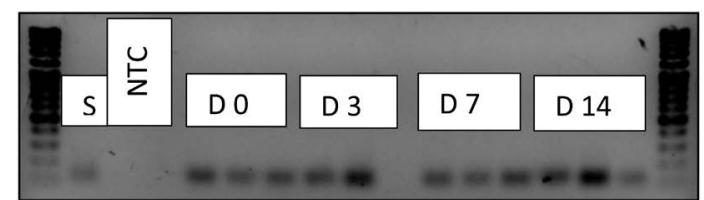

TNF-a mRNA

D0 = Day 0, D3 = Day 3, D7 = Day 7 and D14 = Day 14, S $=$ Standard, NTC $=$ No template control.

Plate 5. The plate represents the corresponding Agarose-Gel electrophoresis post realtime PCR amplification.

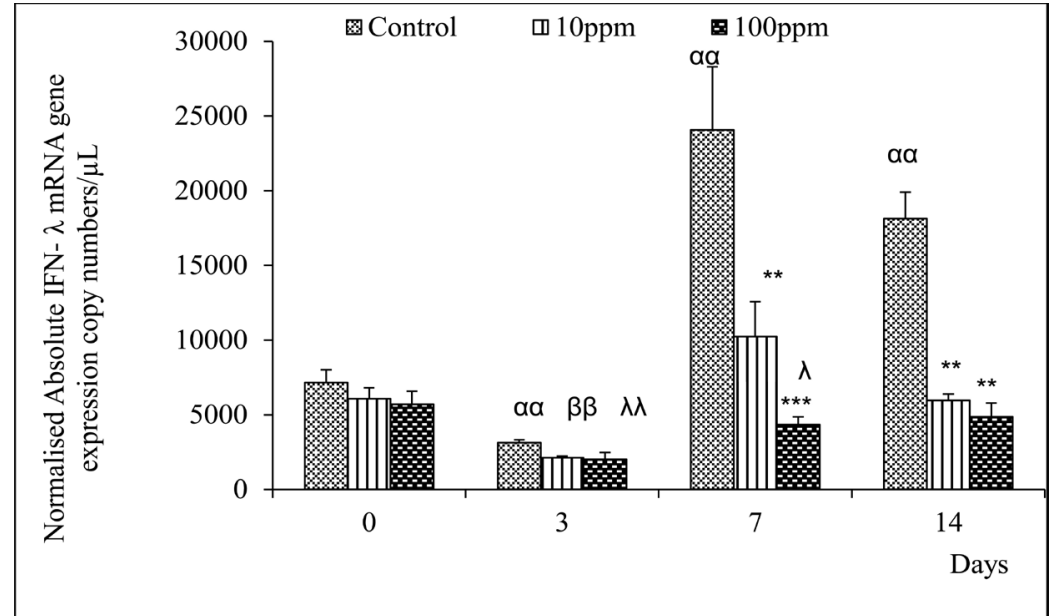

$\alpha \alpha$-significant at $\mathrm{p}<0.01$ compared with control on day $0, \beta \beta$ significant at $\mathrm{p}<0.01$ compared with day 0 , ${ }^{*}$-significant at $\mathrm{p}<0.01$ compared with control, $\beta$-significant at $\mathrm{p}<0.05$ compared with 10 ppm on day $0, \lambda$-significant at $\mathrm{p}<0.05$ compared with $100 \mathrm{ppm}$ on day 0 .

Figure 6. Real-Time PCR Absolute copy numbers of colon IFN- $\lambda$ mRNA gene expression following oral chromium administration before and after colitis induction. Values were normalised with the three reference genes, B-actin, GAPDH and RPL13. 


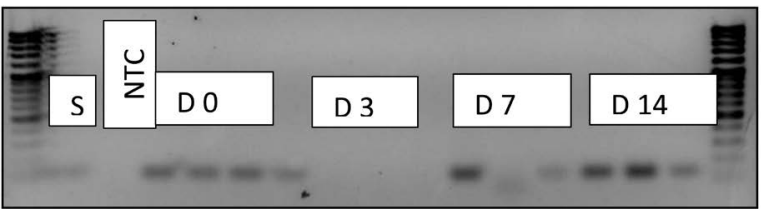

IFN-AmRNA

D0 $=$ Day 0, D3 = Day 3, D7 = Day 7 and D14 = Day 14, S $=$ Standard, NTC $=$ No template control.

Plate 6. The plate represents the corresponding. Agarose-Gel electrophoresis post realtime PCR amplification.

The platelet counts increased in relation to control in the chromium treated groups after the administration period. There is a growing appreciation of roles of platelets in immune system regulation and inflammation [25]. The roles played by platelets during immune responses are observed at sites of its activation and deposition or systemically at locations that are far from platelet activation [25]. The increase in platelet count and reduction in neutrophil-lymphocyte ratio noted in the injured states of chromium treated groups compared to control colon suggest an anti-inflammatory effect. This further suggests that, platelet interactions with inflammatory cells might produce pro-inflammatory responses, which could be beneficial in limiting the progression of infection. In this present study, the platelets pro-inflammatory activities were observed thus accelerating the inflammatory phase of colitis healing. Acetic acid-induced colitis in mice largely mimics clinical form of human colitis especially with the acute inflammatory responses [26].

Certain studies have indicated that an increase in ROS production decreases antioxidant defenses in IBD patients [27] [28], apart from protection by the epithelial layer. Food particles and disease causing organisms may cause inflammation by activating certain unregulated factors within the colon epithelium. The infiltration of polymorphonuclear neutrophils (PMNs) and macrophages can synthesize inflammatory cytokines (and other mediators) that contribute further to oxidative stress [29]. In physiological conditions, exogenous (dietary) and endogenous enzymatic antioxidants protect tissues from dangers posed by ROS. The malondialdehyde, myeloperoxidase, catalase, Superoxide Dismutase and colon total nitrites were essentially within normal range compared with control. The raised SOD, platelet counts, lymphocyte counts and the reduced MPO, NLR and MDA are all suggestive of an anti-inflammatory activity of chromium, partly by its suppression of neutrophil infiltration and consequently reducing its over activation. The suppression of MDA values is an important indicator of reduced ROS activity of which the gastrointestinal tract itself is a major producer [29].

Chemokine and cytokines are released following injuries and inflammatory cells release inflammatory mediators which ultimately cause cell death or programmed cell death [30]. Leukocyte's over-activation is a very important step in this process. The level of MPO, an enzyme mainly existing in neutrophil, reflects the level of neutrophil infiltration. The amount of MPO clearly decreased in chromium treated group which suggests that chromium reduced neutrophil in- 
filtration in vivo.

Trivalent chromium is involved in the structure and expression of genetic information in animals [31] and it also protects RNA from heat denaturation. Chromium is concentrated in cell nuclei and has increased in vitro RNA synthesis in mice [32] thus buttressing the hypothesis of its effect on gene functions. Depletion of rRNAs, especially the $18 \mathrm{~s}$ rRNA noted on day 3 in all groups and both tissues might imply that it was used up in protein synthesis during epithelial restitution. As the functional organelle for protein synthesis, ribosomes bound to the endoplasmic reticulum (ER) perform complex surveillance of various pathologic stresses [33] [34]. Ribosomal alteration by endogenous and external insults can be a trigger of a variety of pathogenic processes, including inflammatory responses [35] [36] [37].

Furthermore, Interleukin-1 mRNA expression was down-regulated in the colon and being an early response pro-inflammatory cytokines acts with TNF- $\alpha$ (another early response pro-inflammatory cytokine). These two cytokines act through similar pathways [38], by enhancing permeability and coagulation property of the endothelium, induction of arrays of both inflammatory and immune response genes [38]. Interleukin-6 mRNA expression was insignificant except by day 14 in the colon. Interleukin- 6 being a complex regulatory cytokine is initially a pro-inflammatory cytokine which then stimulates anti-inflammatory responses through its regulatory influence on TNF- $\alpha$ and IL-1 receptors [39]. This present result is in keeping with the above stated role as continuously elevated levels of IL- 6 was observed during the post injury phases in the colon tissues at all points examined. This suggests that IL-6 is acting as an anti-inflammatory regulator throughout the latter stages of injury and healing in this particular study.

Interleukin-10 is a recognized and established anti-inflammatory cytokine [40] and was up-regulated at all point examined after injury compared with control. It acts by down regulating inflammatory immune responses via suppression of macrophages activities and dendritic cells thus inhibiting TH1 responses [40]. Interleukin-10 is also a potent inhibitor of IFN- $\gamma$ [41]. There was a decrease in IFN- $\lambda$ expression on days 7 and 14 after colitis induction in the chromium groups. Certain researchers early reported that pro-inflammatory cytokines, IFN- $\lambda$ and tumor necrosis factor (TNF) blocked intestinal epithelial cell proliferation (IEC) and delayed healing by promoting IEC programmed cell death [42] [43].

However, TNF- $\alpha$ was down regulated on day 3 post colonic injury compared with the control. TNF- $\alpha$ is usually one of the first set of cytokines released after tissue injury and has a spectrum of activities such as, increasing vascular permeability, stimulation of acute phase protein secretion and induction of many pro- and anti-inflammatory cytokines such as IL-6, IL-8, INF- $\gamma$, and IL-10. Studies on experimental traumatic brain injury models have described strong rise in TNF- $\alpha$ level at injured sites within a few hours following injury, and this cyto- 
kine had returned to baseline within the first 24 hour [41] [44] [45]. TNF- $\alpha$ had most probably been up-regulated at an earlier time and had induced an array of pro and anti-inflammatory cytokines, and by now itself down regulated under the influence of elevated levels of anti-inflammatory agents such as IL-10 and IL-6.

\section{Conclusion}

In conclusion, trivalent chromium promotes healing of acetic acid induced injuries by suppressing reactive oxygen species, inhibiting inflammatory tissue markers and down-regulating pro-inflammatory cytokine genes, while promoting expression of anti-inflammatory cytokine mRNA. This study did not report any adverse effect on the normal tissue exposed to chromium in terms of tissue integrity, generation of oxidative radicals and gene expression. This is very important in allaying fears of toxicity to the gastrointestinal cells and tissues. Finally, consumption of $\mathrm{Cr}^{3+}$-rich natural products may be beneficial for reversal of some gastrointestinal dysfunctions.

\section{Acknowledgements}

Maebashi Institute of Technology, Maebashi, Japan, Professors Tomoo Homma and Toshihiko Kadoya for allowing the use of their laboratories for this study.

\section{Conflict of Interest}

Authors declared no conflict of interest.

\section{Funding}

Partly funded by University of Ibadan, Nigeria (Academic Staff Development Grant) in conjunction with Tertiary Education Trust Fund (TETFund).

\section{References}

[1] Abraham, C. and Medzhitov, R. (2011) Interactions between the Host Innate Immune System and Microbes in Inflammatory Bowel Disease. Gastroenterology, 140, 1729-1737. https://doi.org/10.1053/j.gastro.2011.02.012

[2] Keshavarzian, A., Morgan, G., Sedghi, S., Gordon, J.H. and Doria, M. (1990) Role of Reactive Oxygen Metabolites in Experimental Colitis. Gut, 31, 786-790. https://doi.org/10.1136/gut.31.7.786

[3] Grisham, M.B. (1994) Oxidant and Free Radicals in Inflammatory Bowel Disease. Lancet, 344, 859-861. https://doi.org/10.1016/S0140-6736(94)92831-2

[4] Millar, A.D., Rampton, D.S., Chander, C.L., Claxson, A.W., Blades. S., Coumbe, A. et al. (1996) Evaluating the Antioxidant Potential of New Treatments for Inflammatory Bowel Disease Using a Rat Model of Colitis. Gut, 39, 407-415. https://doi.org/10.1136/gut.39.3.407

[5] Fiocchi, C. (1998) Inflammatory Bowel Disease: Etiology and Pathogenesis. Gastroenterology, 115, 182-205. https://doi.org/10.1016/S0016-5085(98)70381-6

[6] Podolsky, D.K. (2002) Inflammatory Bowel Disease. New England Journal of Medi- 
cine, 347, 417-429. https://doi.org/10.1056/NEJMra020831

[7] Nosal'ova, V., Cerna, S. and Bauer, V. (2000) Effect of N-Acetylcysteine on Colitis Induced by Acetic Acid in Rats. General Pharmacology, 35, 77-81. https://doi.org/10.1016/S0306-3623(01)00094-5

[8] Kanodia, L., Borgohain, M. and Das, S. (2011) Effect of Fruit Extract of Fragaria vesca Leave on Experimentally Induced Inflammatory Bowel Disease in Albino Rats. Indian Journal of Pharmacology, 43, 118-121. https://doi.org/10.4103/0253-7613.75660

[9] National Institute of Health (NIH) (2013) Chromium Dietary Supplement Facts Sheet. National Institute of Health, Bethesda, 1-7.

[10] Mertz, W. (1993) Chromium in Human Nutrition: A Review. Journal of Nutrition, 123, 626-633.

[11] Mertz, W. (1998) Interaction of Chromium with Insulin: A Progress Report. Nutritional Review, 56, 174-177. https://doi.org/10.1111/j.1753-4887.1998.tb06132.x

[12] Stoecker, B.J. (2001) Chromium. In: Bowman, B. and Russell, R., Eds., Present Knowledge in Nutrition, 8th Edition, ILSI Press, Washington DC, 366-372.

[13] Vincent, J.B. (2003) The Potential Value and Toxicity of Chromium Picolinate as a Nutritional Supplement, Weight Loss Agent and Muscle Development Agent. Sports Medicine, 33, 213-230. https://doi.org/10.2165/00007256-200333030-00004

[14] National Institute of Health Publication (1996) Guide for the Care and Use of Laboratory Animals. Revised No. 85-23.

[15] Choudhary, J., Blackstock, W., Creasy, D. and Cottrell, J. (2001) Matching Peptide Mass Spectra to EST and Genomic DNA Databases. Trends Biotechnology, 19, S17S22.

[16] Fukuda, R., Hirota, K., Fan, F., et al. (2002) Insulin-Like Growth Factor 1 Induces Hypoxia-Inducible Factor 1-Mediated Vascular Endothelial Growth Factor Expression, Which Is Dependent on MAP Kinase and Phosphatidylinositol 3-Kinase Signaling in Colon Cancer Cell. The Journal of Biological Chemistry, 277, 3820538211. https://doi.org/10.1074/jbc.M203781200

[17] Morris, G.P., Beck, P.L., Herrigge, M.S., et al. (1989) Hapten Induced Model of Chronic Inflammation and Ulceration in the Rat Colon. Gastroenterology, 96, 795803.

[18] Varshney, R. and Kale, R.K. (1990) Effect of Calmodulin Antagonists on Radiation Induced Lipid Peroxidation in Microsomes. International Journal of Biology, 158, 733-741. https://doi.org/10.1080/09553009014552121

[19] Sinha, K.A. (1972) Colorimetric Assay of Catalase. Analytical Biochemistry, 47, 389-394.

[20] Misra, H.P. and Fridovich, I. (1972) The Role of Superoxide Anion in the Autoxidation of Epinephrine and a Simple Assay for Superoxide Dismutase. Journal of Biological Chemistry, 25, 3170-3175.

[21] Ignarro, L.J., Buga, G.M., Wood, K.S., et al. (1987) Endothelium-Derived Relaxing Factor Produced and Released from Artery and Vein Is Nitric Oxide. Proceedings of National Academy of Sciences, 84, 9265-9269. https://doi.org/10.1073/pnas.84.24.9265

[22] Griess, P. (1879) Bemerkungen zu der abhandlung der H.H., Weselsky und Benedikt. "Ueber einige azoverbindungen." Chemische Berichte, 12, 426-428. https://doi.org/10.1002/cber.187901201117 
[23] Kim, J.J., Shajib, M.S., Manocha, M.M., et al. (2012) Investigating Intestinal Inflammation in DSS-Induced Model of IBD. Journal of Visual Experiments, 60, e3678. https://doi.org/10.3791/3678

[24] Elson, C.O., Sartor, R.B., Tennyson, G.S. and Riddell, H. (1995) Experimental Models of Inflammatory Bowels Disease. Gastroenterology, 109, 1344.

[25] Smyth, S.S., McEver, R.P., Weyrich, A.S., et al. (2009) Platelet Colloquium Participants. Platelet Functions beyond Hemostasis. Journal of Thrombosis Haemostasis, 7, 1759-1766. https://doi.org/10.1111/j.1538-7836.2009.03586.x

[26] Morrell, C.N., Aggrey, A.A., Chapman, L.M. and Modjeski, K.L. (2014) Emerging Roles for Platelets as Immune and Inflammatory Cells. Blood, 123, 2759-2767. https://doi.org/10.1182/blood-2013-11-462432

[27] Lih-Brody, L. Powell, S.R., Collier, K.P., et al. (1996) Increased Oxidative Stress and Decreased Antioxidant Defenses in Mucosa of Inflammatory Bowel Disease. Digestive Diseases and Sciences, 41, 2078-2086. https://doi.org/10.1007/BF02093613

[28] Thomson, A., Hemphill, D. and Jeejeebhoy, K.N. (1998) Oxidative Stress and Antioxidants in Intestinal Disease. Digestive Diseases and Sciences, 16, 152-158. https://doi.org/10.1159/000016859

[29] Bhattacharyya, A., Chattopadhyay, R., Mitra, S. and Crowe, S.E. (2014) Oxidative Stress: An Essential Factor in the Pathogenesis of Gastrointestinal Mucosal Diseases. Physiological Reviews, 94, 329-354. https://doi.org/10.1152/physrev.00040.2012

[30] Iles, K.E., Dickinson, D.A., Watanabe, N., et al. (2002) AP-1 Activation through Endogenous $\mathrm{H}_{2} \mathrm{O}_{2}$ Generation by Alveolar Macrophages. Free Radical Biology and Medicine, 32, 1304-1313.

[31] Pechova, A. and Pavlata, L. (2007) Chromium as an Essential Nutrient: A Review. Veterinarni Medicina, 52, 1-18.

[32] Okada, S., Tsukada, H. and Ohba, H. (1983) Enhancement of Ribonucleic Acid Synthesis by Chromium (III) in Regeneratin Rat Liver. Journal of Inorganic Biochemistry, 19, 95-103.

[33] Deisenroth, C. and Zhang, Y. (2010) Ribosome Biogenesis Surveillance: Probing the Ribosomal Protein Mdm2-p53 Pathway Oncogene. Epub, 29, 204253-204260. https://doi.org/10.1038/onc.2010.189

[34] Steffen, K.K., McCormick, M.A., Pham, K.M., et al. (2012) Ribosome Deficiency Protects against ER Stress in Saccharomyces cerevisiae. Genetics, 191, 107-118. https://doi.org/10.1534/genetics.111.136549

[35] Wan, W., Lim, J.K., Lionakis, M.S., et al. (2011) Genetic Deletion of Chemokine Receptor Ccr6 Decreases Atherogenesis in ApoE-Deficient Mice. Circulatory Research, 109, 374-381. https://doi.org/10.1161/CIRCRESAHA.111.242578

[36] Wier, E.M., Neighoff, J., Sun, X., et al. (2012) Identification of an N-Terminal Truncation of the NF-Kappa B p65 Subunit That Specifically Modulates Ribosomal Protein S3-Dependent NF-kappaB Gene Expression. The Journal of Biological Chemistry, 287, 430. https://doi.org/10.1074/jbc.M112.388694

[37] Yang, H.J., Youn, H., Seong, K.M., et al. (2013) Phosphorylation of Ribosomal Protein S3 and Antiapoptotic TRAF2 Protein Mediates Radio Resistance in Non-Small Cell Lung Cancer Cells. Journal of Biological Chemistry, 288, 2965-2975. https://doi.org/10.1074/jbc.M112.385989

[38] Tsirogianni, A.K., Moutsopoulos, N.M. and Moutsopoulos, H.M. (2006) Wound Healing: Immunological Aspects. Injury, 375, S5-S12. 
[39] WanYong, H., Huynh, K.Y., Swee, K.Y., et al. (2009) Traditional Practice, Bioactivities and Commercialization Potential of Elephantopus scaber Linn. Journal of Medicinal Plant Research, 3, 1212-1221.

[40] Cheville, N.F. (1999) Introduction to Veterinary Pathology. 2nd Edition, Iowa State University Press, Ames, 118-119.

[41] Vitarbo, E.A., Chatzipanteli, K., Kinoshita, K., et al. (2004) TNF Expression and Protein Levels Following Fluid Percussion Injury in Rats: The Effect of Injury Severity and Brain Temperature. Neurosurgery, 55, 416-425. https://doi.org/10.1227/01.NEU.0000130036.52521.2C

[42] Seno, H., Miyoshi, H., Brown, S.L., et al. (2009) Efficient Colonic Mucosal Wound Repair Requires Trem2 Signaling. Proceedings of National Academy of Sciences, 106, 256-261. https://doi.org/10.1073/pnas.0803343106

[43] Goresky, T., Dirisina, R., Sinh, P., et al. (2012) p53 Mediates TNF-Induced Epithelial Cell Apoptosis in IBD. American Journal of Pathology, 181, 1306-1315.

[44] Fan, L., Young, P.R., Barone, F.C., et al. (1996) Experimental Brain Injury Induces Differential Expression of Tumor Necrosis Factor-Alpha mRNA in the CNS. Brain Research. Molecular Brain Research, 36, 287-291.

[45] Knoblach, S.M., Fan, L. and Faden, A.I. (1999) Early Neuronal Expression of Tumor Necrosis Factor after Experimental Brain Injury Contributes to Neurological Impairment. Journal of Neuroimmunology, 95, 115-125.

Submit or recommend next manuscript to SCIRP and we will provide best service for you:

Accepting pre-submission inquiries through Email, Facebook, LinkedIn, Twitter, etc. A wide selection of journals (inclusive of 9 subjects, more than 200 journals)

Providing 24-hour high-quality service

User-friendly online submission system

Fair and swift peer-review system

Efficient typesetting and proofreading procedure

Display of the result of downloads and visits, as well as the number of cited articles

Maximum dissemination of your research work

Submit your manuscript at: http://papersubmission.scirp.org/

Or contact jbm@scirp.org 